\title{
Diversification of Household Income in Rural Areas: Opportunities and Risks of Biomass Energy
}

\author{
Maria Bruna Zolin*
}

Department of Economics, University of Venice, Cannaregio Fond.ta S. Giobbe, 873 30121, Venice, Italy

\begin{abstract}
Within the renewable energy resources, biomasses play a crucial role. The year 2008, might be remembered as the time when the world understood the linkage and interdependence between food and energy. A number of factors including subsidies, high oil prices, increasing demand from emerging countries and lower yields in some countries, as well as lower levels of world food stocks, resulted in soaring food prices. As consequences, number of countries adopted the opportunity to boost the development of biofuel as a solution for energy insecurity, the threat of climate change and to enhance agriculture and rural development. In the Eu rural areas amount for 92 per cent of the EU surface but the per capita income is around the third less. Diversification of household income, aiming at revitalising and avoiding the rural areas' progressive degradation and abandonment is crucial. In fact agriculture can play several roles in addition to its primary function of producing food. The growing attention given to the non agricultural commodity outputs (particularly renewable energy) is a clear example. Rural is not synonymous with decline or with agriculture. The distinctions between rural and urban areas are obsolete and rural areas are not homogenous, with uniform bonds or same opportunity. This study analyses the dimension of renewable energy as a diversification activity in the European rural areas. The objectives of this study are to identify: the key added values of bioenergy production in rural area; the regions/areas benefitting or that might benefit from the promotion of bioenergy production; policies in the agricultural sector that could be designed to ensure benefits to rural areas from the production and provision of bioenergy; which stakeholders are mostly (positively or negatively) affected from the production of biomass.
\end{abstract}

Keywords: Diversification of income, rural areas, biomass energy.

\section{INTRODUCTION}

The industrial revolution in Europe was fuelled by coal, but the continent over time has switched to oil and natural gas. Coal is still used in some countries for heating and electricity; however, concerns on climate change and carbon dioxide emissions could further reduce usage.

Since the energy crises of the 1970s, many industrial nations have launched programmes to develop renewable energy solutions, but the current return of low oil prices is preventing renewable energies from developing on a large commercial scale.

The Annual Energy Outlook 2009 foresees in its Alternative Policy Scenario that the share of renewables in primary energy production by 2030 will double at 14.6 per cent (the biomass share will reach 8.6 per cent) and in 2035 will reach 15.6 per cent. Renewables in consumption are expected to grow to around 11.8 per cent by 2030 and 12.4 per cent by 2035 , according to the U.S. Energy Information Administration [1].

Generally, fuel resources are not abundant in Europe ${ }^{1}$. The EU imports 80 per cent of its oil requirements, with

*Address correspondence to this author at the Department of Economics, University of Venice, Cannaregio Fond.ta S. Giobbe, 873 30121, Venice, Italy; Tel: 2349041 132; Fax: 0412349 176; E-mail: zolin@unive.it

${ }^{1}$ Except for Norway and United Kingdom who have significant, if declining, oil and natural gas resources still available. In 2006 the UK became a net oil importer. Also coal, while abundant in Poland and Germany, is increasingly imported. around 45 per cent of the EU oil imports come from the Middle East, and it is expected that by 2030 the imports percentage will reach 90 per cent. With gas, the dependence on imports is also alarming: the EU imports 60 per cent of its gas requirements, projected to rise to 80 per cent by 2030 and 95 per cent of its current imports come from three countries, with Russia in a monopolistic and dominant position $^{2}[1]$.

Diversifying and ensuring energy supply is a hot topic for Europe

In this scenario the European Commission is trying to improve existing energy networks and boost the production of renewable energy, supporting mainly the smaller and local-scale facilities.

European leaders signed up in March 2007 to a binding EU-wide target to source 20 per cent of their energy needs from renewable, including biomass, hydro, wind and solar power, by 2020 [2]. To meet this objective EU leader agreed a new directive on promoting renewable energies, which set individual targets for each member state [3].

Within the renewable energy resources, biomasses play a crucial role. Biomasses are renewable organic materials, such as wood, agricultural crops or wastes, and municipal wastes, especially used as a source of fuel or energy. Biomass can be burned directly or processed into biofuels such as ethanol and methane.

${ }^{2}$ Russia has used its power as monopolistic gas supplier in neighbouring countries such as the Ukraine and Georgia. 
From this point of view, 2008 might be remembered as the time when the world understood the linkage and interdependence between food and energy. A number of factors including subsidies, high oil prices, increasing demand from emerging countries and lower yields in some countries, as well as lower levels of world food stocks, resulted in soaring food prices.

As consequences, a number of countries adopted the apparent win-win opportunity to boost the development of biofuel as a solution for energy insecurity, the threat of climate change and to enhance agriculture and rural development.
According to the European Commission, in the EU rural areas amount for 92 per cent of the EU surface but the per capita income is around the third less [4].

Diversification of household income, aiming at avoiding the rural areas' progressive degradation is crucial. In fact, multi functionality is used to convey the notion that agriculture can play several roles in addition to its primary function of producing food. The growing attention given to the non agricultural commodity outputs (particularly renewable energy) is a clear example. Rural is not synonymous with decline or with agriculture. The

Table 1. Total Farm Labour Force (AWU and \%)

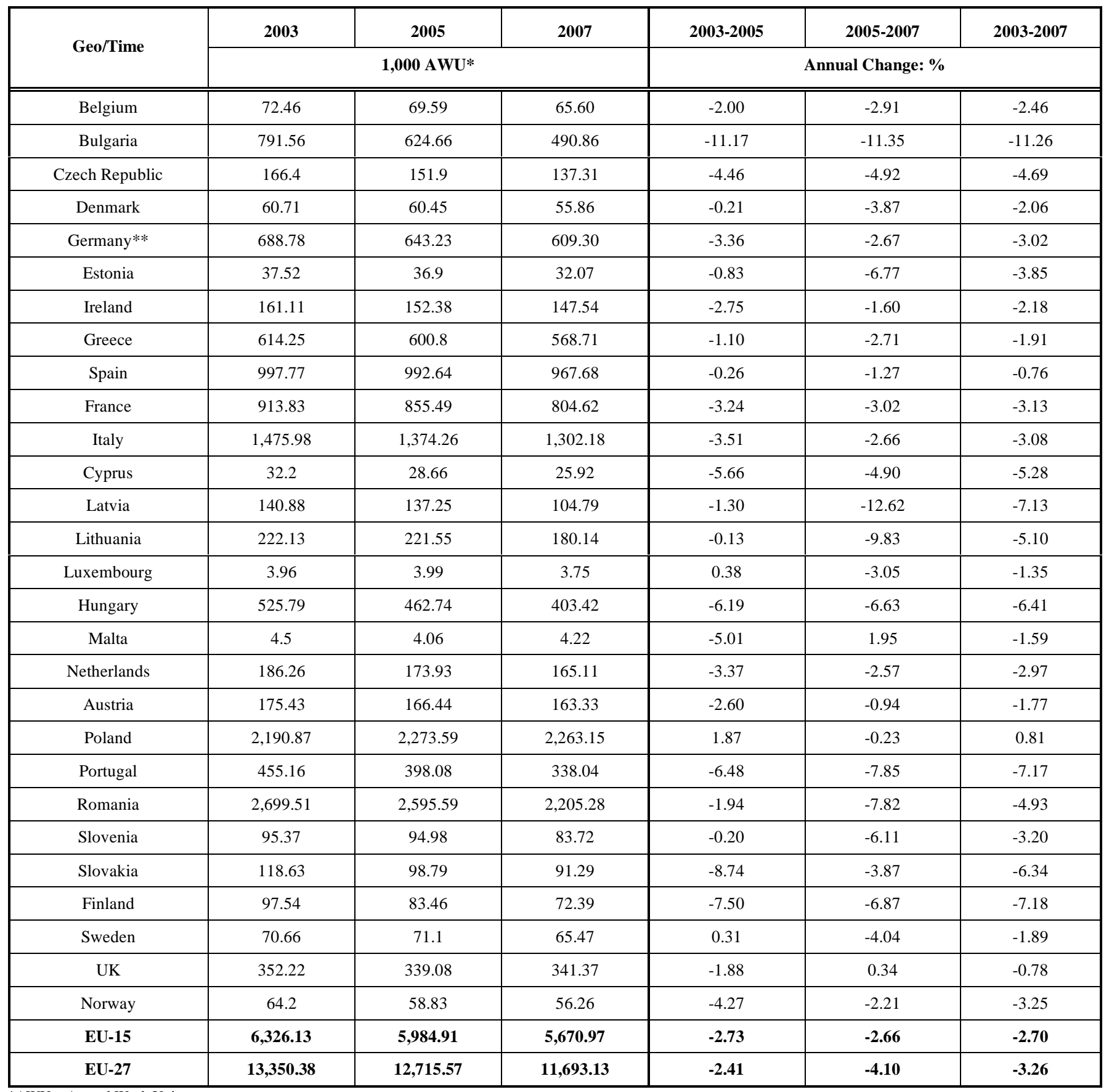

*AWU = Annual Work Unit.

**Including ex-GDR from 1991

Source: Our elaboration on Eurostat data. 
distinctions between rural and urban areas are obsolete and rural areas are not homogenous, with uniform bonds or same opportunity.

This study analyses the dimension of renewable energy as a diversification activity in the European rural areas. The objectives of this study are to identify:

- $\quad$ the key added values of bioenergy production in rural area;

- the regions/areas benefitting or that might benefit from the promotion of bioenergy production;

- policies in the agricultural sector that could be designed to ensure benefits to rural areas from the production and provision of bioenergy;

- which stakeholders are mostly (positively or negatively) affected from the production of biomass.

This paper is divided into five sections. After a brief introduction, the second section describes the agricultural sector, diversification activities and bioenergy production. European rural areas from the point of view of territory, population GVA (Gross Value Added) and employment rate are covered in the third section. The advantages and disadvantages of renewable energy, particularly biomasses, are included in paragraph four. The final section presents some concluding remarks.

\section{THE AGRICULTURAL SECTOR AND DIVERSI- FICATION AND PRODUCTION OF BIOENERGY IN THE EU}

Traditionally the agricultural sector has had the function to provide food and goods through farming and forestry. Modern technologies, pesticides and fertilisers have increased yields from cultivation and at the same time have had widespread negative environmental impacts and, in some cases, negative human health effects.

Until the industrial revolution, the majority of the human population was employed in agriculture. The development of technology has strongly increased agricultural productivity thereby increasing food supplies. Due to public subsides to farmers, mainly in the developed countries; agriculture became a user of synthetic fertilisers and pesticides, selective breeding, mechanisation and a source of water and soil pollution.

The changing role of agriculture can be shown by some figures.

At the beginning of the European Economic Community about a quarter of the total labour force was employed in agriculture (Table 1). The percentages in 2006 in the EU-25 and in the EU-27 were 4.7 and 5.9 (respectively) ${ }^{3}$.

The highest decrease is observed in the new Member States, particularly in Bulgaria and Romania. The Member States with a large quota of farm labour force, in terms of AWU are: Poland (almost 2.3 million) followed by Romania (2.2 million) and Italy (1.3 million). Together they account for almost 50 per cent of the total EU-27 farm labour force.

${ }^{3}$ In Romania this percentage is 30.6 , in Poland 15.8 while in the UK it is 1.4 .
Table 2. All NACE* Branches - Total Euro Per Inhabitant. Gross Value Added (at Basic Prices) and \% Agriculture/Total Gross Value Added

\begin{tabular}{|c|c|c|c|c|c|c|}
\hline \multirow[b]{2}{*}{ Geo/Time } & \multicolumn{3}{|c|}{ All NACE Branches } & \multicolumn{3}{|c|}{$\%$ Agriculture/Total } \\
\hline & 2003 & 2005 & 2007 & 2003 & 2005 & 2007 \\
\hline Austria & 24,900 & 26,600 & 29,500 & 2.0 & 1.5 & 1.7 \\
\hline Belgium & 23,800 & 25,800 & 28,100 & 1.3 & 0.8 & 0.7 \\
\hline Bulgaria & 1,900 & 2,300 & 3,100 & 10.5 & 8.7 & 6.5 \\
\hline Cyprus & 14,700 & 16,200 & 18,100 & 3.4 & 3.1 & 2.2 \\
\hline Czech Republic & 7,200 & 8,800 & 11,100 & 2.8 & 3.4 & 2.7 \\
\hline Denmark & 30,000 & 32,400 & 35,100 & 2.0 & 1.5 & 1.1 \\
\hline Estonia & 5,700 & 7,300 & 10,200 & 3.5 & 4.1 & 2.9 \\
\hline Finland & 24,300 & 26,000 & 29,700 & 3.3 & 3.1 & 3.4 \\
\hline France & 23,100 & 24,600 & 26,600 & 2.6 & 2.4 & 2.3 \\
\hline Germany*** & 23,600 & 24,500 & 26,500 & 0.8 & 0.8 & 1.1 \\
\hline Greece & 14,000 & 15,800 & 17,900 & 5.7 & 5.1 & 3.9 \\
\hline Hungary & 6,300 & 7,500 & 8,600 & 4.8 & 4.0 & 3.5 \\
\hline Ireland & 31,100 & 34,400 & 38,700 & 2.3 & 1.7 & 1.6 \\
\hline Italy & 20,900 & 21,900 & 23,300 & 2.4 & 2.3 & 2.1 \\
\hline Latvia & 3,800 & 5,000 & 8,200 & 5.3 & 4.0 & 3.7 \\
\hline Lithuania & 4,300 & 5,500 & 7,600 & 4.7 & 5.5 & 3.9 \\
\hline Luxembourg & 51,500 & 58,200 & 70,300 & 0.6 & 0.5 & 0.4 \\
\hline Malta & 9,800 & 10,200 & 11,500 & 3.1 & 2.9 & 2.6 \\
\hline Netherlands & 26,200 & 28,000 & 30,800 & 2.3 & 2.1 & 1.9 \\
\hline Poland & 4,400 & 5,600 & 7,100 & 4.5 & 5.4 & 4.2 \\
\hline Portugal & 11,500 & 12,200 & 13,200 & 3.5 & 2.5 & 2.3 \\
\hline Romania & 2,200 & 3,300 & 5,100 & 13.6 & 9.1 & 5.9 \\
\hline Slovakia & 4,900 & 6,300 & 9,200 & 4.1 & 3.2 & 3.3 \\
\hline Slovenia & 11,300 & 12,600 & 15,000 & 2.7 & 2.4 & 2.7 \\
\hline Spain & 16,800 & 18,800 & 21,000 & 4.2 & 3.2 & 2.9 \\
\hline Sweden & 26,900 & 28,500 & 31,700 & 1.9 & 1.1 & 1.3 \\
\hline UK & 24,600 & 27,100 & 29,900 & 0.8 & 0.7 & 0.7 \\
\hline EU-15 & 22,400 & 23,900 & 26,100 & 1.8 & 1.7 & 1.5 \\
\hline EU-27 & 18,600 & 20,100 & 22,200 & 2.2 & 2.0 & 1.8 \\
\hline
\end{tabular}

*NACE = Nomenclature statistique des activités économiques dans la Communauté européenne.

***Including ex-GDR from 1991.

Source: Eurostat.

Comparing the farm labour force with the contribution of the gross value added (GVA) a large disparity between the two indicators can be noticed. This gap could be explained by the fact that many farmers have an additional income from off-farm work and from capital invested outside the agricultural sector or from a large share of part-time agricultural workers. In fact, the structure of the agricultural sector has changed over time: agriculture, traditionally a labour intensive sector, has become capital intensive with many differences among Member States and among different 
areas. With the enlargement the structure is much more diversified, however much it appears convergent. Nevertheless, there is a kind of dualism: large farms with a low share of total farms, occupy a very large percentage of agricultural areas. A very high portion of small farms are run part-time and their incidence on the total area is declining.

One of the most important indicators to measure a country's development is the percentage of the agricultural sector in the total gross value added (Table 2). Even if in absolute terms it increases, it is shrinking all over the European Member States. The largest role of agriculture in GVA is observed in 2003 in Romania (13.6) and Bulgaria
(10.5). After the EU accession the agriculture share also decreased in these countries (Romania and Bulgaria 5.9 and 6.5 respectively).

The same indicator referring to inhabitants highlights the large differences between countries in the economic sectors and the huge difference existing between agriculture and other economic sectors. The common fact is that the percentage of agriculture is declining.

Looking at the Table $\mathbf{3}$, it is evident that the conception regarding the role of agriculture in economic development has undergone an important evolution. If in the past agriculture was often viewed as the passive partner in the

Table 3. Agricultural Area of Total Holdings and Agricultural Area of Holdings with Another Gainful Activity (Hectars/000 and $\%)$

\begin{tabular}{|c|c|c|c|c|c|c|}
\hline \multirow[b]{4}{*}{ Geo/Time } & \multicolumn{6}{|c|}{ Agricultural Area } \\
\hline & & & & \multicolumn{3}{|c|}{ with Another Gainful Activity } \\
\hline & \multicolumn{3}{|c|}{ Total } & \multicolumn{3}{|c|}{$\%$} \\
\hline & 2003 & 2005 & 2007 & 2003 & 2005 & 2007 \\
\hline Austria & 3,257 & 3,266 & 3,189 & 20.8 & 24.4 & 24.6 \\
\hline Belgium & 1,394 & 1,386 & 1,374 & 4.9 & 5.6 & 5.1 \\
\hline Bulgaria & 2,904 & 2,729 & 3,051 & 38.7 & 31.2 & 27.1 \\
\hline Cyprus & 156 & 151 & 146 & 16.7 & 13.9 & 13.7 \\
\hline Czech Republic & 3,632 & 3,558 & 3,518 & 34.8 & 27.8 & 30.0 \\
\hline Denmark & 2,658 & 2,708 & 2,663 & 20.8 & 26.1 & 31.2 \\
\hline Estonia & 796 & 829 & 907 & 28.5 & 20.9 & 15.9 \\
\hline Finland & 2,245 & 2,264 & 2,293 & 30.3 & 34.5 & 33.5 \\
\hline France & 27,795 & 27,592 & 27,477 & 23.7 & 24.3 & 23.9 \\
\hline Germany* & 16,982 & 17,035 & 16,932 & 23.6 & 27.1 & 27.8 \\
\hline Greece & 3,968 & 3,984 & 4,076 & 4.0 & 5.7 & 4.5 \\
\hline Hungary & 4,353 & 4,267 & 4,229 & 42.0 & 34.9 & 37.7 \\
\hline Ireland & 4,298 & 4,219 & 4,139 & 6.5 & 6.0 & 7.0 \\
\hline Italy & 13,116 & 12,708 & 12,744 & 9.4 & 11.8 & 13.5 \\
\hline Latvia & 1,489 & 1,702 & 1,774 & n.a. & 20.6 & 23.8 \\
\hline Lithuania & 2,491 & 2,792 & 2,649 & 8.7 & 4.7 & 4.2 \\
\hline Luxembourg & 128 & 129 & 131 & 14.8 & 21.7 & 23.7 \\
\hline Malta & 11 & 10 & 10 & 9,1 & 10 & 10 \\
\hline Netherlands & 2,007 & 1,958 & 1,914 & 39.3 & 34.1 & 27.2 \\
\hline Poland & 14,426 & 14,755 & 15,477 & 6.3 & 10.7 & 10.2 \\
\hline Portugal & 3,725 & 3,680 & 3,473 & 12.5 & 14.4 & 12.4 \\
\hline Romania & 13,931 & 13,907 & 13,753 & 11.9 & 28.6 & 25.7 \\
\hline Slovakia & 2,137 & 1,879 & 1,937 & 68.9 & 34.5 & 57.3 \\
\hline Slovenia & 486 & 485 & 489 & 6.8 & 7.8 & 7.6 \\
\hline Spain & 25,176 & 24,856 & 24,893 & 4.5 & 7.7 & 8.6 \\
\hline Sweden & 3,127 & 3,192 & 3,118 & 18.5 & 20.2 & 32.6 \\
\hline UK & 16,106 & 15,957 & 16,129 & 32.0 & 39.0 & 39.1 \\
\hline EU-15 & 125,982 & 124,934 & 124,545 & 17.8 & 20.5 & 21.2 \\
\hline EU-27 & 172,794 & 171,996 & 172,485 & 18.0 & 20.9 & 21.3 \\
\hline
\end{tabular}


development process, it is now regarded as an active partner with other economic sectors.

The share of the agricultural area dedicated to other gainful activity is about 20 per cent ${ }^{4}$. In other words about a fifth of the European agricultural surface area is involved in multifunctional activities that in a certain sense explain the numerous benefits that agriculture can provide to a country or area. They include, for example, environmental protection, landscape preservation, rural employment, and, recently, energy security: in addition to providing food and plant-derived products for the population, agriculture can also have provide jobs for rural people and contribute to the viability of the area, create a more stable food supply, and provide other desired environmental and rural outputs.

The highest percentages of land involved in multifunctional activities are observed in the new Member States and in countries where mountain areas are relevant.

The farm sector of the EU shows a great variety in terms of the size of farms. Generally small scale farms dominate the farming structure in the Mediterranean countries, whereas in continental regions the size is bigger. The dual form structure will remain in the EU over time. Table 4 gives the average size of holdings with another gainful activity. The average size of multifunctional holdings has almost a doubled size. The average size is biggest in Slovakia and the Czech Republic (353 and 219 respectively). Malta and Romania have the smallest size holdings (1.9 and 5.7 respectively).

The percentage of agricultural area in holdings with another gainful activity shows, as expected, strong differences between countries. The highest percentage is observed in France, UK and Germany, and the lowest in the smaller farm structures in new Member States. Having regard to holdings with another gainful activity, they appear to be concentrated in Romania (45 per cent of the total) followed at huge distance by France (9.15), Poland (8.46), Italy (8), Germany (6) and the UK (5).

It should also be noted that the smaller the size, the greater is the search for income diversification (such as in Romania). Rosset [5] demonstrated that small farms are multifunctional, more productive and more efficient.

Even if free market is from the economic point of view the best solution because allows countries to specialise in producing goods and services in which they have comparative advantage, allowing consumers to purchase good and services from countries that produce them most efficiently [6], the agricultural sector, mainly in the developed countries, has been, more or less, regulated by specific laws and supported. The reason for this special treatment is well known and they could be summarised as: food security concerns, agricultural income provision, agricultural efficiency concerns, stability of markets, food safety and environmental concerns.

Generally, concern for the environment has increased in most countries over time as far as the environmental awareness among consumers, policymakers and some

\footnotetext{
${ }^{4}$ Any data exists on the disaggregation of the surface among the different
} gainful activities. farmers. With close to a low incidence on labour focus on GDP, the percentage of soil involved in the agricultural sector is really relevant.

The impact of agricultural production on the environment is of great interest. Agriculture produces not only products such as food and feed, but also services.

It has to be remembered that $40-50$ per cent of the European surface area is occupied by the agricultural area and the protection of the environment from this point of view is the protection of the agriculture sector ${ }^{5}$.

There are many differences among the European Member States depending on the presence and the extent of mountain areas where production activity is more difficult because of natural handicaps such as different climate conditions, short growing seasons, steep slopes and low soil productivity. Thus, Sweden and Finland have the lowest agricultural area percentage and the UK and Denmark the highest.

As far as the environment is concerned, one of the major drivers for sustainable agriculture is, and has been, the European Union.

In the Common Agricultural Policy (CAP) during the latest programme period 2007-2013, the main focus has been on the second pillar of the common agricultural policy, known as rural development ${ }^{6}$. The Council Regulation 1698/2005 [7] laid down the general rules governing Community support for rural development and introduced a single instrument to finance rural development policy: the European Agricultural Fund for Rural Development (EAFRD) that contributes to improving:

- the competitiveness of agriculture and forestry;

- the environment and the countryside;

- $\quad$ the quality of life and the management of economic activity in rural areas.

The competitiveness of the agricultural and forestry sector is to be improved by measures aimed at enhancing human potential, physical capital and the quality of agricultural production.

Regarding land management, which is part of improving the environment and the countryside objective, the support is to contribute to sustainable development by encouraging farmers and forest holders to employ methods of land use compatible with the need to preserve the natural environment and landscape and protect and improve natural resources.

Regarding the diversification of the rural economy, the Regulation contains measures on:

- diversification towards non-agricultural activities, support for the establishment and development of micro-businesses, promotion of tourism and the protection, development and management of the natural heritage that contributes to sustainable economic development;

- improving the quality of life in rural areas, with particular focus on renovating and developing villages

\footnotetext{
${ }^{5}$ In the EU the total area of holding in about 50 per cent of the total national area, while the total agricultural area is lower and equals 40 per cent.

${ }^{6}$ The first pillar is market measures.
} 
Table 4. Average Size of Holdings and Holdings with Another Gainful Activity in Hectares, Compared to Agricultural Area and Holdings' Number (\%), 2007

\begin{tabular}{|c|c|c|c|c|}
\hline Geo & Average Size of Total Holdings & \multicolumn{3}{|c|}{ Holdings with Another Gainful Activity } \\
\hline Belgium & 28.6 & 36.8 & 0.19 & 0.14 \\
\hline Bulgaria & 6.2 & 80.2 & 2.25 & 0.76 \\
\hline Czech Republic & 89.3 & 219.5 & 2.87 & 0.35 \\
\hline Denmark & 59.7 & 79.4 & 2.26 & 0.77 \\
\hline Estonia & 38.9 & 74.7 & 0.39 & 0.14 \\
\hline Finland & 33.6 & 40.8 & 2.09 & 1.39 \\
\hline Hungary & 6.8 & 50.1 & 4.33 & 2.34 \\
\hline Ireland & 32.3 & 43.7 & 0.78 & 0.48 \\
\hline Italy & 7.6 & 15.8 & 4.67 & 7.99 \\
\hline Latvia & 16.5 & 43.0 & 1.15 & 0.72 \\
\hline Lithuania & 11.5 & 73.8 & 0.30 & 0.11 \\
\hline Luxembourg & 56.9 & 77.0 & 0.08 & 0.03 \\
\hline Malta & 0.9 & 1.9 & 0.00 & 0.03 \\
\hline Netherlands & 24.9 & 36.8 & 1.42 & 1.04 \\
\hline Spain & 23.8 & 57.1 & 5.81 & 2.75 \\
\hline Sweden & 42.9 & 60.4 & 2.76 & 1.24 \\
\hline UK & 53.8 & 90.5 & 17.13 & 5.12 \\
\hline EU-15 & 22.0 & 47.2 & 71.63 & 41.34 \\
\hline EU-27 & 12.6 & 27.0 & 100.00 & 100.00 \\
\hline
\end{tabular}

and preserving and making the best use of the rural heritage;

- vocational training for economic operators in the above fields and another connected with acquiring skills and running activities in order to prepare and implement the local development strategy.

Finally the Leader segment of the programme consists of:

- a local development strategy designed to select the best development plans by local action groups representing public-private partnerships;

- implementing cooperation projects between areas involved;
- $\quad$ networking of local partnerships.

As far as energy is concerned, the aim of Community farm investment aid is to modernise agricultural holdings to improve their economic performance through better use of the production factors including the introduction of new technologies and innovation, targeting quality, organic products and on/off-farm diversification, including non-food sectors and energy crops, as well as improving the environmental, occupational safety, hygiene and animal welfare status of agricultural holdings. Private forests play an important role in economic activity in rural areas and, therefore, Community aid is important for improving and broadening their economic value, for increasing diversification of production and 
enhancing market opportunities, in sectors such as that for renewable energy, while maintaining the sustainable management and the multifunctional role of forests.

The production of renewable energy has a low share of the total of holdings with another gainful activity. Currently, no relationships appear to exist between the number of holdings with another activity and the number of holdings with production of renewable energy. Nowadays only 6 per cent of the holdings with another gainful activity produce renewable energy (Table 5).

With the CAP Health Check reform interest in renewable energy has increased. The approach now is different and support for renewable energy and for farmers living in rural area is strengthened.
The Health Check provides an extra $€ 3.4$ billion for Member States/regions to spend through their RDPs (Rural Development Programmes) in the period 2010-2013 on any/all of the following areas:

- $\quad$ climate change;

- water management;

- $\quad$ renewable energy;

- biodiversity;

- $\quad$ restructuring the dairy sector;

- innovation linked to any of the above areas.

Multifunctional activity involves almost 10 per cent of European farms. Even if this is a raising phenomenon, resulting in part from the inadequacy of agricultural

Table 5. Total Number of Holdings, Number of Holdings with Another Gainful Activity and Holdings with Renewable Energy Production (Number and \%)

\begin{tabular}{|c|c|c|c|c|c|c|}
\hline \multirow[b]{3}{*}{ Geo/Time } & \multicolumn{4}{|c|}{ Holdings } & \multicolumn{2}{|c|}{ Holdings with Renewable Energy Production } \\
\hline & \multicolumn{2}{|c|}{ Total } & \multicolumn{2}{|c|}{ with Another Gainful Activity } & \multirow{2}{*}{$\begin{array}{c}\text { Total } \\
2007 \\
\end{array}$} & \multirow{2}{*}{$\begin{array}{c}\% \\
2007 \\
\end{array}$} \\
\hline & 2003 & 2007 & 2003 & 2007 & & \\
\hline Austria & 173,770 & 165,420 & 32,550 & 35,580 & 2,010 & 5.6 \\
\hline Belgium & 54,940 & 48,010 & 2,090 & 1,910 & 60 & 3.1 \\
\hline Bulgaria & 665,550 & 493,130 & 27,040 & 10,310 & 0 & 0.0 \\
\hline Cyprus & 45,200 & 40,120 & 2,770 & 2,670 & 0 & 0.0 \\
\hline Czech Republic & 45,770 & 39,400 & 3,720 & 4,810 & 40 & 0.8 \\
\hline Denmark & 48,610 & 44,620 & 6,960 & 10,460 & 1,200 & 11.5 \\
\hline Estonia & 36,860 & 23,340 & 2,750 & 1,930 & 40 & 2.1 \\
\hline Finland & 74,950 & 68,230 & 18,960 & 18,870 & 420 & 2.2 \\
\hline France & 614,000 & 527,350 & 151,390 & 124,650 & n.a. & n.a. \\
\hline Germany & 412,300 & 370,480 & 80,040 & 80,590 & 22,980 & 28.5 \\
\hline Greece & 824,460 & 860,150 & 10,500 & 12,760 & 20 & 0.2 \\
\hline Hungary & 773,380 & 626,320 & 86,640 & 31,830 & 60 & 0.2 \\
\hline Ireland & 135,620 & 128,240 & 6,460 & 6,590 & 210 & 3.2 \\
\hline Italy & $1,963,820$ & $1,679,440$ & 89,510 & 108,780 & 35,40 & 3.3 \\
\hline Latvia & 126,610 & 107,750 & n.a. & 9,840 & 20 & 0.2 \\
\hline Lithuania & 272,110 & 230,270 & 4,510 & 1,500 & 0 & 0.0 \\
\hline Luxembourg & 2,450 & 2,300 & 270 & 400 & 210 & 52.5 \\
\hline Malta & 10,990 & 11,020 & 440 & 430 & 0 & 0.0 \\
\hline Netherlands & 85,500 & 76,740 & 25,400 & 14,160 & 1,860 & 13.1 \\
\hline Poland & $2,172,210$ & $2,390,960$ & 71,100 & 115,150 & 180 & 0.2 \\
\hline Portugal & 359,280 & 275,080 & 35,480 & 20,460 & 50 & 0.2 \\
\hline Romania & $4,484,890$ & $3,931,350$ & 186,570 & 617,690 & 360 & 0.1 \\
\hline Slovakia & 71,740 & 68,990 & 2,810 & 3,150 & 330 & 10.5 \\
\hline Slovenia & 77,150 & 75,340 & 2,870 & 3,120 & 60 & 1.9 \\
\hline Spain & $1,140,730$ & $1,043,910$ & 25,810 & 37,470 & 590 & 1.6 \\
\hline Sweden & 67,890 & 72,610 & 8,720 & 16,830 & 1,270 & 7.5 \\
\hline UK & 280,630 & 299,830 & 45,650 & 69,680 & 1,120 & 1.6 \\
\hline EU-15 & $6,238,950$ & $5,662,410$ & 539,790 & 559,190 & 35,540 & 6.4 \\
\hline EU-27 & $15,021,410$ & $13,700,400$ & 949,420 & $\mathbf{1 , 3 6 1 , 6 2 0}$ & 36,630 & 2.7 \\
\hline
\end{tabular}


incomes, figures show that this is due mainly to Romanian holdings increasing ${ }^{7}$ (from 187,000 in 2003 , before the enlargement, to 618,000 in 2007).

\section{RURAL AREAS}

There is no sole exclusive definition of what constitutes "rural areas".

Actually, there are various methodological approaches proposed by the existing literature; among them, we have to mention: OECD (Organisation for Economic Co-operation and Development) [8]; DG-Agri based on CORINE Land Cover data [9]: using GIS cartography, ${ }^{8}$. The literature also suggests different green areas thresholds, ranging from 70 per cent to 90 per cent; INSOR ${ }^{9}[10]$ classifies a community as rural when the percentage of green areas exceeds 50 per cent of the total area and the density of the population is equal to or less than 300 inhabitants per km2. EUROSTAT, like OECD methodology, is based on the population density of a given area; Council regulation (CE) No 1260/99 [11] laying down general provisions on structural Funds (Article 4) considers rural areas to be those which comply with some specific criteria such as population density, percentage share of agricultural employment in total employment; unemployment rate. The Countryside Agency, UK [8], defines rural areas as settlements with less than 10,000 inhabitants.

The main reasons for so many different approaches are:

the various perceptions of what is (and what is not) rural and of the elements characterising "rurality" (natural, economic, cultural, historical, etc),

the implications of the rural concept go beyond agriculture and cover many economic, social and environmental issues relevant for rural residents and policymakers,

- the inherent need to have a tailor-made definition according to the research undertaken or policy concerned,

- $\quad$ the difficulty collecting relevant data at the level of basic geographical units.

The OECD methodology is the only definition of rural areas internationally recognised. However, the results of this approach are sometimes considered as imperfectly reflecting the rural character of areas, particularly in densely populated regions. The methodology is, therefore, sometimes adapted or replaced by another approach.

This methodology in based on a two step approach: local units are identified as rural if the population is less than 150 inhabitants per square kilometre, and then regions ${ }^{10}$ are classified as:

- $\quad$ Predominantly Rural region (PR): if more than 50 per cent of the population of the region is living in rural communes;

${ }^{7}$ Entry of Romania: 1st January 2007.

${ }^{8}$ These percentages exclude water surfaces.

${ }^{9}$ Italian National Institute for Rural Sociology.

${ }^{10}$ NUTS 3 or NUTS 3.
- Intermediate Region (IR): if 15 per cent to 50 per cent of the population of the region is living in rural local units;

- $\quad$ Predominantly Urban region (PU): if less than 15 per cent of the population of the region is living in rural local units ${ }^{11}$.

Rural areas, according to the OECD classification, are often characterised by low population density, low education and income per capita, but the main problem of rural areas is represented by isolation and resulting economic and social disadvantages, which often mean a low standard and quality of life. Moreover, rural or/and remote areas exhibit one or more of the following characteristics: scarcity or absence of public facilities such as reliable electricity supply, water, access roads and regular transport, and difficult topographical conditions (e.g. lakes, rivers, hills, mountains or deserts), which could render the construction of infrastructures very costly and appear an obstacle to sustainable development. Besides, rural communities face somewhat different issues associated with increases in petroleum and natural gas costs. As energy prices rise, so do household costs for transportation and home heating.

Otherwise, rural areas, most of the time, are areas of considerable natural value, with ideal climatic conditions and rich with natural resources, so the main potentialities of these areas, in terms of economic and social development, could be represented by sustainable tourism and by the utilisation of natural resources for renewable energy applications.

At the European level, by analysing the population in the three types of area, we find that 14.8 and 18.6 percent (respectively UE-15 and UE 27) of the population fall within the Predominantly Rural region area, involving 55 per cent of the territory in the EU-15 and 53 per cent in the EU-27. The Intermediate region appears to be the more evenly balanced in terms of population and total land range. Nearly 50 per cent in the EU-15 and 44 per cent in the EU-27 of the population live in urban communes, which represent just respectively only 11 per cent and 9 per cent of the European territory (Table 6).

A low population density characterises the Predominantly Rural regions, where, we can suppose, mountain areas are widespread (Table 7). This area could also include important natural heritage (mountains, coastline and national parks). The change in population in the studied decade shows a relatively positive situation: the indicator in

\footnotetext{
${ }^{11}$ The Commission has used the OECD methodology in the Strategic Guidelines for RDP 2007-2013. According to the OECD definition, which is based on population density, rural regions account for 92 per cent of the EU territory. Furthermore, 19 per cent of the population live in predominantly rural regions and 37 per cent in significantly rural regions. These regions generate 45 per cent of Gross Value Added (GVA) in the EU and provide 53 per cent of the employment, but tend to lag behind non-rural areas as regards a number of socioeconomic indicators, including structural indicators. In rural areas, per capita income is around a third less ${ }^{11}$, activity rates for women are lower, the service sector is less developed, higher education levels are generally lower, and a smaller percentage of households has access to broadband internet. Remoteness and peripherally are major problems in some rural regions. These disadvantages tend to be even more significant in predominantly rural regions, although the general picture at the EU level can vary substantially between Member States. Lack of opportunities, contacts and training infrastructure are a particular problem for women and young people in remote rural areas [4].
} 
Table 6. Importance of Rural Areas (\%) - NUTS 3, 2004

\begin{tabular}{|c|c|c|c|c|c|c|c|c|c|c|c|c|}
\hline & \multicolumn{3}{|c|}{ Territory in Rural Areas } & \multicolumn{3}{|c|}{ Population in Rural Areas } & \multicolumn{3}{|c|}{ GVA in Rural Areas } & \multicolumn{3}{|c|}{ Employment in Rural Areas } \\
\hline & PR & IR & PU & PR & IR & PU & PR & IR & PU & PR & IR & PU \\
\hline EU-15 & 55.1 & 33.8 & 11.0 & 14.8 & 34.3 & 50.9 & 11.6 & 29.9 & 58.5 & 17.4 & 32.1 & 50.6 \\
\hline EU-27 & 53.1 & 37.9 & 8.9 & 18.6 & 37.7 & 43.7 & 12.3 & 30.8 & 56.9 & 19.5 & 35.6 & 44.8 \\
\hline
\end{tabular}

Note: The total for France and therefore the European aggregates include the overseas departments.

Source: Rural Development in the European Union - Statistical and Economic Information, Report 2007.

the Predominantly Rural regions increases, even if a lower level, than in the Predominantly Urban Regions.

Table 7. Population Density and Change in Population NUTS 3

\begin{tabular}{|c|c|c|c|c|c|c|}
\hline \multirow{2}{*}{} & \multicolumn{3}{|c|}{ Inhab/Km ${ }^{2}-\mathbf{2 0 0 4}$} & \multicolumn{3}{c|}{ Inhab/Km ${ }^{2} \mathbf{~ 1 9 9 5 ~ t o ~ 2 0 0 4 ~}$} \\
\cline { 2 - 7 } & PR & IR & PU & PR & IR & PU \\
\hline \hline EU-15 & 32.0 & 121.2 & 551.6 & 0.6 & 5.4 & 16.5 \\
\hline EU-27 & 39.9 & 113.1 & 558.3 & 0.1 & 2.0 & 17.9 \\
\hline
\end{tabular}

Note: for France and, consequently, for the European aggregates, the overseas departments are covered.

Source: Rural Development in the European Union - Statistical and Economic Information, Report 2007

As far as the Utilised Agricultural Area (UAA) is concerned $^{12}$, the highest percentage is located in the Predominantly Rural regions. Where the evaluation takes into consideration the population (we must remember that around 15 per cent is located in this area) the average number of units of land per inhabitant is also higher than that of the urban areas.

In the urban area the land per inhabitant is very low, both in terms of total area and UAA. The population density, on the contrary, tends to be higher. Inevitably, the major share of the services units and of the manufacturing units is concentrated here. The comparison between these areas is particularly unfavourable to the predominantly rural regions $[12,13]$.

If strategies are tools for development, which one are the most effective?

Rural areas are not only a productive territory but also a consumptive space for all kinds of new demands The multifunctionality of agriculture, at the heart of debate two decades ago, is the way in which the agricultural sector has an exceptionally range of outputs and within them the production of bioenergy [14].

Production of bioenergy can contribute to rural development through new job creation, diversification of rural employment opportunities and income generation [15].

\footnotetext{
${ }^{12}$ In the EU-27 arable land represents almost 61 per cent of the total, while in the EU-15 it represents 56 per cent. Permanent pasture covers the 33 per cent of the EU-27 land and permanent crops 6 per cent (in the EU-15, 36 and 8 per cent respectively).
}

\section{RENEWABLE ENERGY: BIOMASS AND RURAL AREA}

The function of the EU energy policy is to drive sustainable processes, leaving the single Member States to deal with specific areas of intervention. The European guidelines and support are more complex and lengthy, yet, at the same time, generally, more lenient, than national ones.

Currently, the main European guidelines and regulations concerning energy and renewable energy could be summarized in the following documents:

1. European Parliament's directive, Promotion of the use of energy from renewable sources, 2009 [16];

2. Communication from the Commission Second Strategic Energy Review. An EU energy security and solidarity action plan, 2008 [17];

3. Communication from the Commission to the European Council and the European Parliament: An energy policy for Europe, 2007 [3];

4. Communication from the Commission Renewable Energy Road Map. Renewable energies in the 21st century: building a more sustainable future, 2006 [18];

5. Communication from the Commission Action Plan for Energy Efficiency: Realising the Potential. Saving $20 \%$ by 2020,2006 [2];

6. Green Paper on Energy Efficiency or Doing More with Less, June 2005 [19];

7. Directive 2001/77/CE on Electricity Production from Renewable Energy Sources [20].

The Communication from the Commission to the European Council and the European Parliament An energy policy for Europe (January, 2007) [3] represents a strategic review of the European energy situation and introduced a complete set of European Energy Policy measures (the so called 'energy' package). The new European energy policy includes main topics and objectives fixed till then by the Renewable Energy Road Map (2006) [18], Action Plan for Energy Efficiency (October 2006) [2] and the Green Paper on Energy Efficiency (June 2005) [19]. The main objectives could be summarised as follows:

1. Establishing the internal energy market;

2. Ensuring a secure energy supply, and minimising the EU's vulnerability concerning external energy dependency;

3. Reducing greenhouse gas emissions; 
4. Developing energy technologies;

5. Considering the future of nuclear energy;

6. Implementing a common international energy policy.

With the Directive on the promotion of the use of energy from renewable sources [21], the EU established a common framework for the promotion of energy from renewable sources and committed itself to completing the initiative "2020-20".

In particular, the Directive establishes that each Member State shall ensure that the share of energy from renewable sources, in gross final consumption of energy in 2020, is at least its national overall target for the share of energy from renewable sources in that year [21]. With regard to transport, each Member State shall ensure that the share of energy from renewable sources in all forms of transport in 2020 is at least 10 per cent of final consumption of energy in transport in that Member State. As far as biofuels are concerned, with effect from 2017, the greenhouse gas emission savings from the use of biofuels and other bioliquids shall be 50 per cent. After 2017 it shall be 60 per cent for biofuels and bioliquids produced in installations whose production has started from 2017 onwards. Finally, Member States shall introduce in their building regulations and codes appropriate measures in order to increase the share of all kinds of energy from renewable sources in the building sector.

With regard to biomasses, the following must not be overlooked:

Commission of the European Communities, Biomass Action Plan (December 2005) [22].

Commission of the European Communities, An EU Strategy for biofuels (February 2006) [23].

The biomass action plan presents measures aimed at intensifying energy production from wood and agricultural waste by offering incentives based on market mechanisms and the elimination of barriers that hinder the development of the market. These incentives will enable Europe to reduce its dependence on fossil fuels, curb greenhouse gas emissions and stimulate economic growth in rural areas.

At European level, biomasses/waste tops the list of renewable energy production followed by hydroelectric power.

Two thirds of the renewable energy in Europe is generated from biomass.

Biomass resources are the total amount of organic materials (wood, agricultural crops, manure or wastes and municipal waste) that could be used as source of fuel or energy ${ }^{3}$.

If vegetable biomass is the result of the photosynthesis process of plants, it can be equally applied both to animal and vegetable derived material ${ }^{14}$. Burning biomass (biopower) is not the only way to release its energy. It can be converted to other typologies like biofuels and bioproducts.

\footnotetext{
${ }^{13}$ Biomass excludes organic material which has been transformed by biological processes into substances such as coal or oil.

${ }^{14}$ Although fossil fuels have their origin in ancient biomass, they are not considered biomass because they contain carbon that has been out of the carbon cycle for a very long time.
}

The most common form of biomass is wood. Another source of biomass is garbage (municipal solid waste). In addition to utilisation of wastes and residues, biomass can be produced by the dedicated production of crops for energy production.

Nearly half of the biomass energy used by households is derived from wood. In rural areas, wood is often a suitable alternative for fossil fuels, because it is amply available and most people are not connected to a natural gas or heat grid.

As it is well known, the development of electricity from solid biomass is lagging behind expectations at the EU level even though it is cost efficient in countries where sufficient exploitable wood waste potential exists.

In 2005 , the breakdown of renewable energy produced in the EU by source was as follows: $66.1 \%$ from biomass, $22.2 \%$ from hydropower, $5.5 \%$ from wind power, $5.5 \%$ from geothermal energy and $0.7 \%$ from solar power (thermal and photovoltaic). The situation in the EU-15 and the EU-27 is shown in Table 8.

The production of renewable energy from forestry is higher than from agriculture and the highest growth rate is observed in the old Member States.

The largest contributors to the total biomass from agriculture and forestry are Germany and France.

Certainly the long term traditions in the biomass sector and the importance of the forestry industry combined with the fact that most plants are large scale industrial units are strong success factors in the development of the biomass electricity sector in Alpine and Scandinavian countries. The development in Germany is mainly driven by medium scale generation units ${ }^{15}$. Some countries (such as Italy, Czech Republic, Hungary, Slovak Republic) allow for the option of co-firing solid biomass in conventional power plants.

As is generally recognised, there is a close inter-linkage between food security, climate change and bioenergy.

Climate change is projected to have significant impact on agricultural performance, altering the availability of water, soil and biodiversity; this at the end will influence food security [24-26]. Bioenergy places further demands on agricultural products as well as on commodity prices [27, 28].

The main advantages of biomass can be summarised in the following $[29,30]$ :

- Biomass fuels are more environmentally friendly in many ways than most fossil fuel.

- Inexhaustible fuel force;

- Cuts back on waste and supports agricultural products. In fact biomass fuel from agriculture wastes may be a secondary product that adds value to agricultural crops;

\footnotetext{
${ }^{15} \mathrm{Up}$ to $20 \mathrm{MW}$.
} 
Table 8. Production of Renewable Energy from Agriculture and Forestry (2005)

\begin{tabular}{|c|c|c|c|c|c|c|}
\hline \multirow[b]{2}{*}{ EU-12 } & \multicolumn{2}{|c|}{$\begin{array}{c}\text { Production of Renewable } \\
\text { Energy from Agriculture (kToe) }\end{array}$} & \multicolumn{2}{|c|}{$\begin{array}{l}\text { Production of Renewable } \\
\text { Energy from Forestry (kToe) } \\
\text { (Wood and Wood Waste) }\end{array}$} & \multicolumn{2}{|c|}{$\begin{array}{l}\text { Average Annual Growth } \\
\text { Rate of Renewable Energy } \\
\text { from Forestry } 2000-2005(\%)\end{array}$} \\
\hline & 3,376 & & 14,966 & & 7.25 & \\
\hline EU-15 & 3,002 & & 46,917 & & 2.59 & \\
\hline EU-25 & 3,376 & & 58,126 & & 3.62 & \\
\hline EU-27 & 3,376 & & 62,099 & & 3.63 & \\
\hline \multirow{3}{*}{ The Three Most Important Countries: } & Germany & $1,595.2$ & France & $9,430.0$ & Czech Republic & 36.95 \\
\hline & France & 523.3 & Sweden & $7,937.0$ & Slovakia & 31.82 \\
\hline & Italy & 361.2 & Germany & $6,906.0$ & Hungary & 22.94 \\
\hline
\end{tabular}

- Use of locally produced biomass instead of imported fossil fuels provides an economic income for local activities and could increase income and jobs in rural areas;

- $\quad$ Less money spent on fossil resources.

The disadvantages of biomass are:

- Low level of economic performance;

- $\quad$ Still an expensive source, both in terms of producing biomass and converting it to alcohol on a small scale where there is most likely a net loss of energy;

- $\quad$ Could contribute a great deal to global warming and pollution if burned;

- It is not economical to transport biomass fuels over long distances, therefore power plants usually are located near the sources of biomass;

- $\quad$ Lack of technologies capable of ensuring high energy performances within the conversion processes; some biomass conversion projects are from animals and are relatively small and therefore limited;

- $\quad$ Research and subsidies are needed to reduce the costs of production;

- Low level of public opinion awareness;

- Land used for energy crops may be in demand for other purposes, such as faming, conservation, resorts or agricultural use (mainly for food);

- Serious loss of fertility in soils in which crop for biomass are produced (no organic matter to the soil) ${ }^{16}$.

The main obstacle in advancing renewable energy over the last decades has been cost-effectiveness. With a few number of exception (such as large hydropower combustible biomass for heat), the average costs of renewable energy are generally not competitive with fossil fuel prices.

In the scenario where costs appear higher than benefits, the support of public authorities is essential. Without such aid market forces would result in only limited diffusion of

\footnotetext{
${ }^{16}$ To limit the environmental negative impacts of conventional agriculture, biomass has to be produced in a sustainable manner. There exist a large range of approaches such as integrated pest management or no tillage cultivation $[33,34]$
}

renewable energy in a few market niches. The public involvement can be justified as a mean to correct negative externalities resulting from the use of fossil fuel and the achievement of greater efficiency by stimulating technical innovation [31]. Renewable energy contributes to the preservation of the public good of clean air and climate stability. Due to the non-excludable and non-rival characteristics of the air and climate stability public goods, private actors are not interested to invest in something that everyone can acquire free of charge (market failure).

Renewable energy has indeed to grow. However, using crop land to produce fuel could raise food prices and using wood for energy could see a decrease in forestation, but if used in a sustainable way they could support and improve income of smaller farmers in rural areas, mainly in those close to marginalisation.

The use of renewable energy in rural areas has been growing more and more, due to the rising prices of conventional fuels and the ready availability of resources in these areas (especially biomass and hydropower but also solar and wind power).

The most common application of renewable energy for rural services are cooking (biomass direct combustion; biogas from household-scale digesters; solar cookers); lighting (hydropower; biogas; solar/wind hybrid systems); process motive power for small industry (small hydropower; biomass); water pumping for agricultural and domestic use (mechanical wind pumps; solar pumps); heating and cooling for crop drying, other agricultural processing and hot water (biomass; biogas; solar power).

Renewable energy, therefore, can be considered a contribution to "access" strategies in rural and remote areas, since it helps to increase services for rural populations that do not have access to central electric power networks. Moreover, renewable energy technologies represent a costeffective alternative to grid extension in remote areas and in developing countries. Renewable resources, in fact, in terms of economic costs, are a convenient choice in relation to conventional fuels and traditional grid extension, whose costs are often prohibitive for a developing country.

These are the reasons why many national rural electrification policies and programmes have explicit mandates for renewable energy and include it as a possible 
aid to reduce the isolation of remote areas and to improve the quality of life of the population living there ${ }^{17}$.

\section{CONCLUDING REMARKS}

The concept of rural (or urban) can have different definitions, influenced according to the economic, social, political needs or contexts.

The European Commission pays particular attention to rural development by increasing the measures and the resources available in order to enhance the environment, rural space and the quality of life in rural areas and also provides incentives to diversify economic activities in rural. Despite the fact that macroeconomic indicators highlight the decreasing weight given to agriculture, especially in the more industrialised countries, it continues to play a vitally important multifunctional role if we consider that a large amount of the total land is invested in agricultural activities.

However, the use of cultivable crop land for fuel remains strongly controversial. Biomass production depends on land, water, fertilisers and/or pesticides and energy. The strengthening of biomass production creates competition for land and water, conflicts based on food security or energy security and feasible environmental improvement, when there is an absence of opportune and dedicated policies [32].

Both agricultural commodities and energy prices have increased significantly in recent years. In the past no significant correlation between them appeared to exist, but many authors and researches state the correlation has now strengthened. As far as wood is concerned, it is worth noting that wood has a standing tradition in rural areas due to its availability $[33,34]$, sustainability and the fact that it is an environmentally friendly, renewable natural resource. Wood also represents a significant source of income for forest owners in the context of forest restitution processes. In this case, an increase in demand for forest products could see a decrease in forestation. However a study [35], which examined the connection between economic growth and the growth of forests in India, concluded that as a result of several of India's policies (economic incentives, conservation methods, trade measures that limited importation of forest products) forest owners have been given an incentive to increase the supply of trees ${ }^{18}$.

Moreover, the European biomass energy framework has highlighted a strong tendency to invest in renewable energies. Two thirds of the renewable energy in Europe is generated from biomass. Nearly half of the biomass energy used by households is derived from wood. In rural areas, wood is often a suitable alternative for fossil fuels, because it is amply available and most people are not connected to a natural gas or heat grid.

\footnotetext{
${ }^{17}$ Some example can be founded in rural electrification programmes of Latin America (Bolivia, Chile, Guatemala, Mexico), Asia (Bangladesh, China, India and many others) but also Africa (Senegal has incorporated solar power into its rural electrification efforts and increased the rural electrification rate by an additional 3 per cent).

${ }^{18}$ Furthermore, the researchers do not support the assertion that increased agricultural productivity increases forestation by decreasing the need for expansion of agricultural land, and that the growth in rural employment increases tree area by moving labour out of forest-resource extraction.
}

If rural areas could definitely benefit from the production of biomass, the study highlights that larger farms would benefit most and that the direct effect of transferring income from the general taxpayer to farm owners, in these cases, would be higher. There is also a kind of territorial concentration. Northern Europe is favoured if compared to Mediterranean countries, because of the know-how, the quantity of raw materials (cereals, wood...), the culture and the climatic and social specificities [36]

Actually, renewable energy has been assuming an increasing importance in recent years as a possible solution to global problems such as the increasing energy demand (in particular in developing countries, where population and GDP are growing faster than elsewhere), the shortage of conventional energy resources, the uncertainty of energy supplies and the resulting increasing energy costs; as well as, of course, the problem of atmospheric pollution and climate change [37].

Non-conventional energies are used especially in rural areas, where renewable resources abound and can play an extremely important role, contributing to improve the standards of life of local populations. Rural areas, in fact, can become places to carry out new patterns of development, through natural resources preservation, their rational use and their re-use, starting with environmental protection, energy independence and public participation in the management of new environmental supply systems. However, the integration of renewable energy production within local rural development processes is fundamental. A number of studies, in fact, link rural areas' centrality for energy production with two different possible paths: on the one hand rural development, on the other hand modernisation. In the first case, energy production is integrated in agricultural activity, supporting the creation of a local productive system, enabling local policies and participative initiatives, which are developed thanks to local ability to attract resources and to use knowledge in order to implement local development processes. Local communities are fundamental in this path; their strength is dominant and external contributions merely functional for local development.

In the modernisation path, industrialisation of agricultural activities prevails; these lose their original characteristics and become agro-energy companies, which only produce raw materials for industrial manufacturing [38].

Renewable energy, therefore, can represent an important development opportunity in rural areas, but it's necessary that localities and local populations are able to implement participation and mobilisation processes and to intercept (and to govern) global flows/influences and resulting opportunities.

Even now the biggest obstacle for renewable energy is represented by the costs gap caused by subsidies for fossil and atomic energies and non-internalised external costs. To ensure the real success of renewable energy it is therefore necessary to develop, prioritise and execute appropriate strategies to achieve fair market conditions, mainly in rural or remote areas where the low quality of life could strongly influence the abandonment of these areas, with a further deterioration of the environment. 


\section{ACKNOWLEDGEMENT}

I am grateful to the anonymous reviewers for the helpful comments.

\section{REFERENCES}

[1] EIA. Annual Energy Outlook 2009, the projection to 2030. Energy Information Administration, 2009.

[2] Commission of the European Communities. Communication from the commission action plan for energy efficiency: realising the potential. Saving 20 percent by 2020, Bruxelles, 2006.

[3] Commission of the European Communities. Communication from the commission to the European council and the European parliament: An energy policy for Europe, Bruxelles, 2007.

[4] Council decision on Community strategic guidelines for rural development (programming period 2007 to 2013), 20 February 2006.

[5] Rosset P. The multiple functions and benefits of small farm agriculture in the context of global trade negotiations. Development 2000; 43(2): 77-82.

[6] Tomek WP. Agricultural product prices. United States of America: $4^{\text {th }}$ ed, 2003.

[7] Council regulation (EC) No 1698/2005 of 20 September 2005 on Support for rural development by the European Agricultural Fund for Rural Development (EAFRD) [Official Journal L 277 of 21.10.2005]

[8] OECD.Creating rural indicators: Paris, 1994

[9] Agri DG. GIS Analysis of 'rural' areas-EU25 (communal level). Intermediate report, 2004

[10] INSOR. Comuni urbani, comuni rurali - per una nuova classificazione; Franco Angeli: Milano, 1994.

[11] Council regulation (EC) No 1260/99 of 21 June 1999 laying down general provisions on the Structural Funds [Official Journal L 161 of 26.06.1999].

[12] Ellis F. Rural livelihoods and diversity in developing countries. Oxford: Oxford University Press 2000.

[13] Biggs S, Ellis F. Evolving themes in rural development 1950s2000s. Dev Policy Rev 2002; 19(4): 437-48.

[14] OECD. The Future of rural policy: from sectoral to place-based policies in rural areas. Paris, 2003.

[15] Cassin M, Zolin MB. Can wind energy make a real contribution to improve the quality of life of rural/remote areas? The European Union and India compared. Transit Stud Rev 2009; 16(3): 735-54.

[16] European Parliament's and Council Directive 2009/28/EC. Promotion of the use of energy from renewable sources and amending and subsequently repealing directives 2001/77/EC and 2003/30/EC, 2009.

[17] Commission of the European Communities. Second Strategic Energy Review. An EU energy security and solidarity action plan. Brussels, 2008.

[18] Commission of the European Communities. Renewable energy road map. Renewable energies in the 21st century: building a more sustainable future, Brussels, 2006.
[19] Commission of the European Communities. Green paper on energy efficiency or doing more with less, Bruxelles, 2005.

[20] European Union and Council of European Union, directive 2001/77/CE on electricity production from renewable energy source, Brussels, 2001.

[21] Directive of the European parliament and of the council on the promotion of the use of energy from renewable sources COM (2008)0019 - C6-0046/2008 - 2008/0016(COD).

[22] Commission of the European Communities. Biomass action plan, Brussels, 2005

[23] Commission of the European Communities. An EU Strategy for biofuels, Bruxelles, 2006.

[24] FAO. Global climate change and agricultural production, Rome, 1996.

[25] IFRI. Climate change: impact on agriculture and costs of adaptation. Washington D.C., USA 2009.

[26] Commission of the European Communities. The role of European agriculture in climate change mitigation, Brussels, 2009.

[27] Mitchell D. A note on rising food prices. The World Bank development prospects group, July 2008.

[28] Andreosso O'-Callaghan B, Zolin MB. Land, biofuels and food security. In: Andreosso O'Callaghan B, Zolin MB, Eds. Current Issues in Economic Integration. Ashgate 2010; pp. 113-17.

[29] Wyman E. Biomass ethanol: technical progress, opportunities, and commercial challenges. Ann Rev Energy Environ 1999; 24: 189226.

[30] Domac J, Richards K, Risovic S. Socio-economic drivers in implementing bioenergy projects. Biomass Bioenergy 2005; 28(2): 97-106.

[31] Kustas G, Lindberg C, Steenblik R. Biofuels: at what cost? Government support for ethanol and biodiesel in the European Union. A report for the international institute for sustainable development. Geneva, 2007.

[32] Berndes G, Hoogwijk M, van der Broek R. The contribution of biomass in the future global energy supply: a review of 17 studies. Biomass Bioenergy 2003; 25: 1-28.

[33] Reijenders L. Conditions for the sustainability of biomass based fuel use. Energy Policy 34; 2006: 863-76.

[34] Muller A. Sustainable agriculture and the production of biomass for energy use. Zurich, June 2008

[35] Foster AD, Rosenzweig MR. Economic growth and the rise of forests. Q J Econ 2003; 118(2): 601-37.

[36] Dufey A. Biofuels production, trade and sustainable development: emerging issues. London: International Institute for Environment and Development 2006.

[37] Peskett L, Slater R, Stevens C, Dufey A. Bio fuels, agriculture and poverty reduction. Overseas Development Institute: Natural Resource Perspectives 2007.

[38] Carrosio G, Prestia A. Flows and fixities of the rural areas: mobility of local communities and the energy question, presented at XXII Congress of the European Society for Rural Sociology, Wageningen 2007

(c) Maria Bruna Zolin; Licensee Bentham Open.

This is an open access article licensed under the terms of the Creative Commons Attribution Non-Commercial License (http://creativecommons.org/licenses/by$\mathrm{nc} / 3.0 /$ ) which permits unrestricted, non-commercial use, distribution and reproduction in any medium, provided the work is properly cited. 